\section{An investigation of Chinese junior high school teachers' and students' attitudes towards EFL writing}

Yang, Yingjie $\square$

University of Southern Queensland, Australia (u1040470@umail.usq.edu.au)

Received: 23 April 2015

Available Online: 15 June 2015

Revised: 27 May 2015

DOI: $10.5861 /$ ijrse.2015.1209

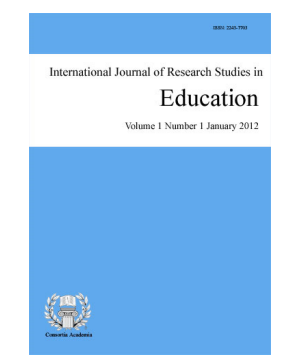

Accepted: 3 June 2015

ISSN: 2243-7703 Online ISSN: 2243-7711

OPEN ACCESS

\title{
Abstract
}

This study investigated Chinese junior high school teachers' and students' attitudes mainly about their worries, perceptions, and beliefs towards EFL writing, which was conducted by a mixed research method. 25 participants were involved in a survey questionnaire that consists of three parts: (1) demographical information, (2) measure of attitudes, and (3) comments on EFL writing. The attitudinal measures with a five-point Likert scale questionnaire showed that EFL writing was ignored in EFL class, but participants expected to focus on that. Furthermore, the results observed from a paired t-test quantitatively indicated that these teachers and students considered EFL writing as a difficult and important skill and they believed that it is possible to improve their EFL writing skill. On the other hand, there was an individual facet-to-face interview to justify these results in the survey, in which, that the root reasons of EFL writing is a weakness skill, the difficulties of performing writing, and the lack of opportunities to practice it, were found. Based on these findings in survey questionnaire and interview, several pedagogical implications were discussed consequently in order to: (i) increase the practice opportunities, (ii) use correct language learning strategies, (iii) overcome the first language barrier, (iv) keep ongoing learning, and (v) reflect the process, quality, and outcome of EFL writing, which are effective ways to enhance the EFL writing skill.

Keywords: EFL writing; perception of writing; learning attitude; attitudes towards EFL; writing skill; practice opportunities; language learning strategies 


\section{An investigation of Chinese junior high school teachers' and students' attitudes towards EFL writing}

\section{Introduction}

Brown (2001) stated that listening and speaking are learned naturally and simultaneously when acquiring a foreign or second language, whereas reading and writing are taught and trained by the related knowledge: the learning behaviour, cognitive process and specific culture. Mastering writing is very difficult for the language learners since it requires a high and complex level of language control (Murcia \& Olshtain, 2000). Harris and Cunningham (1994) further argued that writing is a complicated process involving a series of forward and backward movements from the writer's ideas to the written contexts; hence writing is a difficult skill to teach and learn especially in an EFL setting (Ingels, 2006; Latif, 2007; MacIntyre \& Gardner, 1989). Nevertheless, the weight of speaking task and practice is heavily involved in the EFL class through communicative language teaching approach in many junior high schools in China, while writing has a very small portion.

Many EFL learners think that once they can speak well and they can eventually write well. Brown (2001) pointed out writing is not simply to represent the speaking content in written form, but more complicated. Writing is more than outputting the accurate sentences and paragraphs (Hedge, 2005). To make an analogy, swimming is different from walking. Writing encourages deep thinking, which is a process of exploring, presenting and accessing writer's thoughts and meanings. Zamel (1983) argued the process of writing is a dynamic, non-sequential and interactive process, which involves sub-processes of planning, collecting data, drafting, revising, rewriting and editing. Writing is necessary to be focused in this circumstance. This paper draws attention to the Chinese junior high school teachers' and students' attitudes towards writing in EFL class.

This study attempted to explore the teaching and learning situation of EFL writing in a junior high school setting, in which, 25 participants' attitudes to EFL writing were scrutinized in a questionnaire survey. In particular, that whether these teachers' and students' attitudes are similar or different and to what degrees were identified through the quantitative approach. Then, this study explained the purpose of conducting a qualitative interview to probe the participants' thoughts and feedbacks in a deep way, to find out what their worries, perceptions, and beliefs while instructing and performing EFL writing, and to justify the majority of the participants think that they can improve their EFL writing skill in the qualitative observation. Finally, there were some pedagogic discussions about the learning and teaching EFL writing in the junior high schools.

\section{Literature review}

Attitude was defined as human being's instinctions feelings, prejudice or bias, preconceived notions, fears, threats, and convictions about any specified topic by Gardner (1980), thus attitude is an essential factor to influence one's perception on anything and to decide how one responses to the world. Gardner (1985) had claimed: "attitude is thus linked to a person's values and beliefs and promotes or discourages the choices made in all realms of activity, whether academic or informal." Wenden (1991) classified attitude into three areas: cognitive, affective and behavioural in order to propose an integrate definition of attitude from the psychological understandings. First of all, the cognitive component is the thoughts, beliefs and perceptions about the objects. Secondly, the affective component is about one's feelings: good or bad, like or dislike, prefer or against, and emotional reactions in regard to an object. The third component refers to behaviour that is a particular action or tendency of selecting the certain learning behaviours (Gardner, 1985; Lambert, 1967; Wenden, 1991).

Undoubtedly, there are many influencing factors for foreign language learning, for instance, age, gender, aptitude, intelligence, personality-characteristics, attitude, motivation, anxiety, culture barrier, learning quality and so on. Fakeye (2010) contended that attitude is one of the most important factors that impact on learning a 
An investigation of Chinese junior high school teachers' and students' attitudes towards EFL writing

foreign language. On the basis of a sociolinguistic point of view, Starks and Paltridge (1996) believed that learning a language closely relates to the attitudes to the language, since learning is unconsciously influenced by attitudes. The attitude towards a foreign language is about the speakers or learners interacting that target language's functions and contexts. Ellis (1994) pointed out that the language learners have different attitudes toward the target language, the language user, related culture, and social value of the language, while these learners are possible to find themselves through social and cultural settings by reflecting their attitudes toward language.

Attitudes with both psychological and social factors affect the language learning, the relationship between attitude and performance has been examined entirely (Mathewson, 1994). Many researchers put efforts to find out how attitude affects language learning and to justify the achievement between the attitudes towards a language and language performance (Baker, 1988; Dörnyei \& Csizér 2002; Gardner \& Lambert, 1972; Masgoret \& Gardner, 2003). Karahan (2007) argued the positive language attitudes offer the learners a positive orientation in language learning and enhance the language proficiency too. Ellis (1994) maintained that the language learners' attitudes impact on the level of second or foreign language proficiency achievement. In addition, the attitudes influence the language learners' proficiency achievement, instead of their achievement influencing their attitudes of language learning (Schibeci \& Riley, 1986). In consequence, many researchers concluded that positive language attitudes enhance the language proficiency and lead positive language learning outcomes.

Liu (2010) proposed an analytical study for contrasting Chinese and American senior high school students in English writing and found that the American high school students showed most positive attitudes toward writing content than the Chinese students. In this study, the Chinese students think vocabulary, pattern, content and grammar are very important in writing; meanwhile vocabulary was the first priority out of these four aspects. This clearly indicated that Chinese EFL students have worries in linguistics matters. In another observation of twenty first-year undergraduate students whose first language is German, Pickard (1996) found that these EFL students preferred comprehensive tasks - the reading and listening activities to participating the speaking and writing production tasks. Such results revealed that the attitude towards EFL writing is negative. To find out the root reasons of negative attitudes towards EFL writing, Sever (1998) focused on the primary EFL pedagogy and found that the EFL teachers have responsibilities to lead whether a negative or positive attitude towards writing to students in class. That implies students' impression of writing attitude can be influenced by teachers, for example, Akkaya and Kirmiz (2010) noticed that a boring writing class definitely causes a negative attitude.

Moreover, Gonzalez, Chen and Sanchez (2001) identified that the Chinese culture and discourse patterns impact on the EFL learners' writing. Similarly, Yu (2012) analysed the discourse and pragmatic problems for the Chinese college students' EFL writing with the teaching contexts from the understanding of textual organization and pragmatic strategy. She noticed the Chinese native culture, thought and lack of sufficient pragmatic strategy cause the problem of discourse pattern and cohesion. Along the same line, Choi (1988) analysed the Korean EFL learners' written text structure; by contrast, Kobayashi (1984) investigated the rhetorical writing patterns for the Japanese EFL learners. However, Seyabi and Tuzlukova (2014) suggested that the majority of school and university students have lexical and content problems in EFL writing and the university students' perceptions of the problems and related strategies are more assertive than the school students. This study finally recommended that critical and creative thinking with ideas, knowledge and content should be emphasized in school and university's EFL writing curriculum. In spite of that, using strategic writing technique is also an effective way to enhance the EFL writing skill and attitude (Okasha \& Hamdi, 2014).

\subsection{Significance of the study}

Based on the discussion above, there are many studies on EFL writing, which took into account the major problems existing in performing EFL writing, the reasons behind these problems, the strategies and techniques to develop the writing skill, and some perceptions of teaching and learning EFL writing, but a few of them concerned with the attitudes towards EFL writing in details. Only a few findings with fragments were captured in 
the previous studies, so there were not enough evidences to verify the root reasons about the attitudes towards EFL writing and to support the relationship between the teaching and learning attitudes and EFL writing performance. Thus, this study provided an attempt to establish a relationship between the teachers' and students' attitudes and the EFL writing achievement.

As a matter of fact, many previous researches neither examined whether teachers and students put same attitudes towards EFL writing or different, nor emphasized on the EFL writing attitudes in junior high schools. Then, this study filled a gap of the teachers' and students' attitudes towards EFL writing on a basis of the junior high school settings, because so many studies concern with the EFL writings at either primary or tertiary pedagogical level. Although writing attitude has not been defined clearly yet, in this study the EFL teachers' and students' worries, perceptions, and beliefs, are recommended as a board definition for attitude with relation to EFL writing.

Yu (2012) pointed out writing has two goals in regard to the importance of EFL writing, one is for the purpose of language acquisition and the other is about the practice of writing skill. Systematically, the study integrated the two goals to look at the EFL learners' learning attitude complementary with their teachers' teaching attitude, and drilled into to how and why their writing attitudes influence EFL writing performance and achievement. There were four measures: (i) grammatical and syllabus support, (ii) the first language and culture barriers, (iii) use of language learning strategies, and (iv) the practice opportunity for EFL writing, were involved in this study to identify and justify the sophisticated attitudes towards EFL writing.

\subsection{Purpose of the Study}

Zhao (2014) strongly argued that writing has always been a problem in the EFL classes in China, nevertheless the root of students' difficulties in EFL writing has not been found yet (Lee, 2003). This study aims to develop an understanding by examining the EFL writing's teaching and learning situation in the junior high schools in China. To examine the teachers' and students' attitudes toward EFL writing is not limited in a particular teaching and learning approach, for example, the task-based approach, the genre approach, the process approach, the content approach or the product approach, but analysed and answered the research questions with a mixed method extensively. For this purpose, this study proved that the EFL writing skill is possible to be promoted and enhanced with positive teaching and learning attitudes. Maintaining positive feelings towards a language, to some degrees, will bring about ease and confidence in learning a second or foreign language.

\subsection{Research questions}

This study aims to seek answers for the following four questions:

$>\quad$ What are the junior high school teachers' and students' attitudes towards EFL writing?

$>\quad$ Do the junior high school teachers treat the EFL writing in a similar or different way with their students? To what extend?

$>\quad$ Whether the junior high school teachers and students have a positive attitude to perform EFL writing? If not, why not?

$>\quad$ What are the pedagogical implications that can be implemented in teaching and learning EFL writing in the junior high schools in the near future?

\section{Method}

\subsection{Rationale}

This study was designed and conducted by a mixed method, which comprises the characteristics of both quantitative and qualitative methods. However, the mixed method takes the research problem as its fundamental 
An investigation of Chinese junior high school teachers' and students' attitudes towards EFL writing

concern and also matches the researching techniques to deal with the relevant problems (Creswell, 2012). To begin with a survey, which is a closed questionnaire, there were twelve attitudinal measures with a five-point Likert scale for the participating teachers and students to rate their opinions about the attitudes towards EFL writing. Scotland (1998) stated that positivism is about objectivism to apply the deductive method to seek knowledge with an objective outcome. That means the findings of study is to identify why and how the EFL teachers and students put such attitudes towards EFL writing. Moreover, whether the teachers and students have similar or different attitudes are identified by a t-test. Based on positivism, the survey used the quantitative data to test and proves previous finding. One of the important features of positivism is to adapt the natural science methodology to the social research (Creswell, 2013). Accordingly, the positivism trends and the reality of EFL writing attitudes could be captured and analysed through this quantitative approach.

Nonetheless, the social phenomena are more complicated than the nature science; there is another qualitative observation in order to increase the reliability and validity of the study. Obviously, research is often took place in a target group to build up knowledge and theory by inductive method, Scotland (1998) stated that interpretivism is based on the phenomena in real world, and it subjectively explores, understands and solves the educational problems with different participants (Cohen, Manion, \& Morrison, 2007). Therefore, a semi-structured interview was organised to check the accuracy of result for the survey in this study, to explore any further worries, perceptions and beliefs of the junior school teachers' and students' attitudes towards EFL writing, and to justify these participants' feedback in the interview. This qualitative observation is also a complementary and important contribution to this study, because it certainly offers pedagogical implementations.

\subsection{Participants}

There were 25 participants including 16 students and 9 teachers from different junior high schools in China, who were randomly selected by the researcher. These EFL students were around 14 years old, with an equal demographical distribution. They started to study English from grade 3 in primary school and in general, their English language proficiency level equals to level 1 by ISLPR, the Australian ESL proficiency standard (Ingram \& Wylie, 2007). Half the students share Mandarin as mother tongue, but the rest students speak different Chinese dialects. Every primary student chooses the similar courses under the national curriculum requirement in China, while the English language is one compulsory subject. On the other hand, there were 5 female and 4 male teachers involved in this study who teach EFL at different grades in different junior high schools. They all hold a bachelor degree and five of them graduated with an English language major. Their age was diversified from 25 to 45 years old.

\subsection{Procedure}

The survey (Appendix I) was initially proposed to the participants with three parts. The first part was about the participants' background information including gender, age, first language, years of learning / teaching English, and the teachers' education background. Then, these participants were required to rate their opinions (from 1 - strongly disagree to 5 - strongly agree) in regard to the criteria of their worries, perceptions and beliefs towards EFL writing in a closed questionnaire. The third part of the survey was about these participants' additional comments. If the participants did not provide any feedback for their attitudes towards EFL writing in written form, the researcher still had an opportunity to observe through the interview session.

It is necessary to consider the ethical issues in the whole session of this study, especially designing and processing the survey. The researcher had clearly explained the research purpose orally at the beginning and also declared in the instruction section in the survey. To be polite with all participants is an important key to build up a trusted relationship between the researcher and participants (Gay, Mills, \& Airasian, 2006). Some participants might be aware of their opinions to be released to public, so the results are anonymous, and the relevant information is keeping confidentially. All the participants are volunteering collaborators in this study, thereby it is also important to follow the Chinese political and educational policy in primary schools, for instance, whether 
Yang, Y.

the individual face-to-face interview is allowed in this case.

Besides the researcher explained the research purpose, providing instructions of doing the survey, reminding them not being influenced by any non-scientific sayings, and presenting their own opinions and feelings about EFL writing independently, are the guide to drive the results more reliable and valid. All the teachers and students were individually examined and interviewed, because some shy and coward students might be worried about providing negative comment or feedback. Apparently, there should not be any interaction or communication among the participants, whereas these participants were encouraged to talk to the researcher freely in individual interview, which is a probe into conversation: (1) to check what the participants saying is similar or different to the results in the survey, (2) to justify a similar or different result and whether a positive or negative attitude, and (3) to guide the conversation in Chinese language to find out root reasons of why they have such attitudes, in order to observe a more reliable and valid result. To sum up, the researcher needs to encourage the participants to talk and to take notes by himself in the interview session.

\subsection{Pilot survey and interview}

There was a pilot survey and interview before demonstrating the study, which was a preparation to check whether the questionnaire is well designed or not, to identify possible problem the participants may have, and to evaluate the responses are enough to collect and analyse data. The survey's Chinese version is also available; meanwhile the Chinese language is encouraged to be used in the interview in order to make the study more smoothly and successfully.

\subsection{Data collection and analysis}

Data was collected and summarized in the six tables below, while t-test was analysed by the SPSS program. The researcher also translated several key findings after all conversations in interview.

\section{Results}

\section{Table 1}

Descriptive statistics of participates' demography information

\begin{tabular}{lccccc}
\hline Students & Number of participants & Percentage & Teachers & Number of participants & Percentage \\
\hline Male & 8 & $50.00 \%$ & Male & 4 & $44.44 \%$ \\
Female & 8 & $50.00 \%$ & Female & 5 & $55.56 \%$ \\
Total & 16 & $100.00 \%$ & Total & 9 & $100.00 \%$ \\
\hline
\end{tabular}

Table 2

Criteria for interpreting the mean value of participants' attitudes towards EFL writing

\begin{tabular}{|c|c|c|}
\hline Mean Value & $\begin{array}{l}\text { The teachers' attitudes towards } \\
\text { EFL writing }\end{array}$ & $\begin{array}{l}\text { The students' attitudes towards } \\
\text { EFL writing }\end{array}$ \\
\hline $4.21-5.00$ & Strongly Agree & Strongly Agree \\
\hline $3.41-4.20$ & Agree & Agree \\
\hline $2.61-3.40$ & Uncertain & Uncertain \\
\hline $1.81-2.60$ & Disagree & Disagree \\
\hline $0.00-1.80$ & Strongly Disagree & Strongly Disagree \\
\hline
\end{tabular}


An investigation of Chinese junior high school teachers' and students' attitudes towards EFL writing

Table 3

The mean value \& level of agreement for the teachers' attitudes worries, perceptions, and beliefs towards EFL writing

\begin{tabular}{|c|c|c|c|}
\hline \# & Questions & Mean & Level of agreement \\
\hline \multicolumn{4}{|c|}{$\begin{array}{c}\text { Teachers' worries about the difficulties in EFL writing } \\
\end{array}$} \\
\hline 1 & $\begin{array}{l}\text { Writing is a difficult productive skill when learning English as } \\
\text { Foreign Language, because the vocabulary choice, grammar structure, } \\
\text { and collocation usage are a challenge part for learning and applying; }\end{array}$ & 4.11 & Agree \\
\hline 2 & $\begin{array}{l}\text { From comprehensive to productive, there are differences and/or gaps } \\
\text { existing between understanding and expression; }\end{array}$ & 3.78 & Agree \\
\hline 3 & $\begin{array}{l}\text { There are few good strategies to support EFL writing, meanwhile the } \\
\text { effort put in EFL writing is not enough; }\end{array}$ & 3.56 & Agree \\
\hline \multirow[t]{2}{*}{4} & $\begin{array}{l}\text { ESL writing is an important skill, but it is very difficult to emphasise } \\
\text { and process ESL writing through communicative language teaching } \\
\text { since speaking dominating the class; }\end{array}$ & 3.11 & Uncertain \\
\hline & Average & 3.64 & Agree \\
\hline \multicolumn{4}{|c|}{ Teachers' perceptions of the importance of EFL writing } \\
\hline 5 & $\begin{array}{l}\text { There should be sufficient resources from the teacher, syllabus, and } \\
\text { curriculum to support EFL writing's teaching and learning procedure; }\end{array}$ & 3.89 & Agree \\
\hline 6 & $\begin{array}{l}\text { Attention should be paid on culture barriers and the obstacle between } \\
\text { L1 and L2 while engaging EFL writing; }\end{array}$ & 3.78 & Agree \\
\hline 7 & $\begin{array}{l}\text { Language learning strategies are important in EFL writing and there } \\
\text { should be relevant supports from the EFL teachers and learners in the } \\
\text { EFL class; }\end{array}$ & 2.44 & Disagree \\
\hline \multirow[t]{2}{*}{8} & $\begin{array}{l}\text { A lack of writing practice in EFL class in terms of the amount of time, } \\
\text { tasks, training techniques, and output/productive opportunities; }\end{array}$ & 3.89 & Agree \\
\hline & Average & 3.50 & Agree \\
\hline \multicolumn{4}{|c|}{ Teachers' beliefs with the expectation for EFL writing } \\
\hline 9 & $\begin{array}{l}\text { Beside the language knowledge, the support from teacher and } \\
\text { curriculum, getting valuable feedback from the learning and } \\
\text { performing of EFL writing is also a motivational factor; }\end{array}$ & 3.22 & Uncertain \\
\hline 10 & $\begin{array}{l}\text { Language knowledge is learnt to accompany culture knowledge in } \\
\text { order to write accurately and naturally; }\end{array}$ & 4.22 & Strongly agree \\
\hline 11 & $\begin{array}{l}\text { That to reflect the quality of teaching and learning the EFL writing } \\
\text { with relevant strategies is necessary and helpful; }\end{array}$ & 3.78 & Agree \\
\hline \multirow[t]{2}{*}{12} & $\begin{array}{l}\text { The EFL writing skill can be improved by sufficient effort, } \\
\text { professional training and ongoing practice. }\end{array}$ & 4.00 & Agree \\
\hline & Average & 3.81 & Agree \\
\hline
\end{tabular}

Table 3 indicates that eight out of total twelve items (item 1, 2, 3, 5, 6, 8, 11, \& 12) were agreed by the teachers, who also strongly agreed with item 10 - that "language knowledge is learnt to accompany culture knowledge in order to write accurately and naturally". However, item 4 and 9 were in uncertain status that means the teachers were not sure how to deal with the EFL writing through communicative language teaching, nor motivate and feedback their students when performing the EFL writing. The rest was disagreed by the teachers in survey, which is item 7 - "language learning strategies are important in EFL writing and there should be relevant supports from the EFL teachers and learners in the EFL class". This is because the teachers do not have too many good strategies and cooperative learning between the students is hardly taking place. There is no strongly disagreed item according to the mean value in table 3. Generally the teachers think that there are some difficulties in teaching EFL writing, for example, the grammar knowledge, gaps between understanding and expression, and few good strategies. However, they paid attention on the importance of EFL writing in terms of curriculum support, first language barrier, and the practice opportunities. The teachers also believed the EFL writing skill are trainable. 
Yang, Y.

Table 4

The mean value \& level of agreement for the students' attitudes worries, perceptions, and beliefs towards EFL writing

\begin{tabular}{|c|c|c|c|}
\hline \# & Questions & Mean & Level of agreement \\
\hline \multicolumn{4}{|c|}{$\begin{array}{l}\text { Students' worries about the difficulties in EFL writing } \\
\end{array}$} \\
\hline 1 & $\begin{array}{l}\text { Writing is a difficult productive skill when learning English as } \\
\text { Foreign Language, because the vocabulary choice, grammar structure, } \\
\text { and collocation usage are a challenge part for learning and applying; }\end{array}$ & 4.56 & Strongly agree \\
\hline 2 & $\begin{array}{l}\text { From comprehensive to productive, there are differences and/or gaps } \\
\text { existing between understanding and expression; }\end{array}$ & 3.38 & Uncertain \\
\hline 3 & $\begin{array}{l}\text { There are few good strategies to support EFL writing, meanwhile the } \\
\text { effort put in EFL writing is not enough; }\end{array}$ & 4.00 & Agree \\
\hline \multirow[t]{2}{*}{4} & $\begin{array}{l}\text { ESL writing is an important skill, but it is very difficult to emphasise } \\
\text { and process ESL writing through communicative language teaching } \\
\text { since speaking dominating the class; }\end{array}$ & 3.75 & Agree \\
\hline & Average & 3.92 & Agree \\
\hline \multicolumn{4}{|c|}{ Students' perceptions of the importance of EFL writing } \\
\hline 5 & $\begin{array}{l}\text { There should be sufficient resources from the teacher, syllabus, and } \\
\text { curriculum to support EFL writing's teaching and learning procedure; }\end{array}$ & 4.06 & Agree \\
\hline 6 & $\begin{array}{l}\text { Attention should be paid on culture barriers and the obstacle between } \\
\text { L1 and L2 while engaging EFL writing; }\end{array}$ & 3.38 & Uncertain \\
\hline 7 & $\begin{array}{l}\text { Language learning strategies are important in EFL writing and there } \\
\text { should be relevant supports from the EFL teachers and learners in the } \\
\text { EFL class; }\end{array}$ & 3.88 & Agree \\
\hline \multirow[t]{2}{*}{8} & $\begin{array}{l}\text { A lack of writing practice in EFL class in terms of the amount of time, } \\
\text { tasks, training techniques, and output/productive opportunities; }\end{array}$ & 3.81 & Agree \\
\hline & Average & 3.78 & Agree \\
\hline \multicolumn{4}{|c|}{ Students' beliefs with the expectation for EFL writing } \\
\hline 9 & $\begin{array}{l}\text { Beside the language knowledge, the support from teacher and } \\
\text { curriculum, getting valuable feedback from the learning and } \\
\text { performing of EFL writing is also a motivational factor; }\end{array}$ & 3.94 & Agree \\
\hline 10 & $\begin{array}{l}\text { Language knowledge is learnt to accompany culture knowledge in } \\
\text { order to write accurately and naturally; }\end{array}$ & 3.81 & Agree \\
\hline 11 & $\begin{array}{l}\text { That to reflect the quality of teaching and learning the EFL writing } \\
\text { with relevant strategies is necessary and helpful; }\end{array}$ & 3.00 & Uncertain \\
\hline \multirow[t]{2}{*}{12} & $\begin{array}{l}\text { The EFL writing skill can be improved by sufficient effort, } \\
\text { professional training and ongoing practice. }\end{array}$ & 4.44 & Strongly agree \\
\hline & Average & 3.80 & Agree \\
\hline
\end{tabular}

Similarly, table 4 indicated that the students strongly agreed with that there are some difficulties in performing EFL writing (item 1), that nonetheless can be improved with efforts, training, and ongoing practice (item 12). On average, students considered EFL writing as a difficult skill since item 3 and 4 clearly stated that "there are few good strategies to support EFL writing and the effort in EFL writing is not enough", and it is very difficult to emphasize and process the EFL writing through communicative language teaching with a big portion of speaking skill. Secondly, with the students' perceptions of the importance of EFL writing, they agreed item 5, 7 , and 8 except item 6 . The students did not realized the first language and culture barrier (item 6), which causes the understanding and expression gap in EFL writing. Thus, item 2 and 6 in uncertain status. In addition, item 9 and 10 were agreed by the students, which enhanced the students' belief in improve EFL writing. However, the rest item 11 - "that to reflect the quality of teaching and learning the EFL writing with relevant strategies is necessary and helpful" was in uncertain, because many students did not overview and reflect the learning by themselves. There was not any disagreed or strongly disagreed item in table 4 . 
An investigation of Chinese junior high school teachers' and students' attitudes towards EFL writing

Table 5

Differences between the teacher and student' attitudes worries, perceptions, and beliefs towards EFL writing

\begin{tabular}{|c|c|c|c|c|c|c|}
\hline \multirow[b]{2}{*}{ \# } & \multicolumn{2}{|c|}{ Teachers $(n=9)$} & \multicolumn{2}{|c|}{ Students $(n=16)$} & \multirow{2}{*}{ T Calculated } & \multirow{2}{*}{ Sig. (2-tailed) } \\
\hline & Mean & $\mathrm{SD}$ & Mean & SD & & \\
\hline 1 & 4.11 & 0.60 & 4.56 & 0.51 & -1.8985 & 0.0702 \\
\hline 2 & 3.78 & 0.83 & 3.38 & 0.96 & 1.0985 & 0.2834 \\
\hline 3 & 3.56 & 0.88 & 4.00 & 0.82 & -1.2418 & 0.2268 \\
\hline 4 & 3.11 & 0.78 & 3.75 & 0.77 & -1.9679 & 0.0613 \\
\hline Average & 3.64 & 0.83 & 3.92 & 0.94 & -0.7787 & 0.4708 \\
\hline 5 & 3.89 & 0.60 & 4.06 & 0.68 & -0.6608 & 0.5154 \\
\hline 6 & 3.78 & 0.67 & 3.38 & 0.89 & 1.2844 & 0.2118 \\
\hline 7 & 2.44 & 0.73 & 3.88 & 0.72 & -4.7440 & $0.0001 * *$ \\
\hline 8 & 3.89 & 0.60 & 3.81 & 0.83 & 0.2642 & 0.7940 \\
\hline Average & 3.50 & 0.88 & 3.78 & 0.77 & -0.8012 & 0.4312 \\
\hline 9 & 3.22 & 0.83 & 3.94 & 0.77 & -2.1148 & $0.0455^{*}$ \\
\hline 10 & 4.22 & 0.67 & 3.81 & 0.75 & 1.4092 & 0.1722 \\
\hline 11 & 3.78 & 0.67 & 3.00 & 0.63 & 2.8518 & $0.0090 * *$ \\
\hline 12 & 4.00 & 0.71 & 4.44 & 0.73 & -1.4696 & 0.1552 \\
\hline Average & 3.81 & 0.79 & 3.80 & 0.83 & 0.0260 & 0.9795 \\
\hline
\end{tabular}

Table 5 displayed the paired t-test results with the differences between the teachers' and students' attitudes towards EFL writing. Hence three items (7, 9, \& 11) were identified between the teachers' and students' opinions with a significant difference at $5 \%$ level $(p<0.01)$, which implies that their attitudes to EFL writing are different, for example, item 9 - "beside the language knowledge, the support from teacher and curriculum, getting valuable feedback from the learning and performing of EFL writing is also a motivational factor" was understood differently between them. Teachers might think there are not feedbacks from students since there is no peer learning in class, while students might be interested in cooperative learning, group writing, or pair work. However, there were two more items $(1 \& 4)$ were very close to the significant different level, if at $5 \%$ level $(p<0.05)$. The rest seven items $(2,3,5,6,8,10 \& 12)$ were closely similar for the two variables, in which the teachers and students put a similar attitude towards EFL writing.

To sum up, the mean value of teachers' worries, perceptions, and beliefs were 3.64, 3.50 and 3.81, whereas students were with $3.92,3.78$, and 3.80 , both of them were eventually 'agreed' and tested by paired test with the results in table 5. Thus, the teachers and students not only have a similar attitude in terms of their worries, perceptions, and beliefs towards EFL writing, but also they do have a positive attitude in teaching and learning EFL writing.

Table 6

Data derived from interview, the most frequent comments about the EFL writing attitude

\begin{tabular}{|c|c|c|c|c|}
\hline Item & Specific comment & $\%$ teachers & $\%$ students & Rank \\
\hline 1 & lack of opportunity to practice & $88.89 \%$ & $93.75 \%$ & 1 \\
\hline 2 & first language barrier & $77.78 \%$ & $68.75 \%$ & 2 \\
\hline 3 & language learning strategies & $66.67 \%$ & $81.25 \%$ & 3 \\
\hline 4 & keep learning ongoing & $22.22 \%$ & $43.75 \%$ & 4 \\
\hline 5 & reflect quality and outcome of EFL writing & $33.33 \%$ & $12.50 \%$ & 5 \\
\hline
\end{tabular}

These five items were talked deeply during the interview session and they were ranked in table 6 . The results observed in interview were very similar to the findings in the survey. According to these concerns, (i) to increase the practice opportunities, (ii) to use correct language learning strategies, (iii) to overcome the first language barrier, (iv) to keep the learning ongoing, and (v) always to reflect the quality and outcome of EFL writing, are effective ways to enhance the EFL writing skill. These comments will be discussed in the pedagogical discussion in this paper. 


\section{Pedagogical discussion}

\subsection{To use the known knowledge and content to increase the practice opportunities in EFL class}

The teachers and students consider EFL writing as a difficult productive skill and they agree that the vocabulary choice, collocation usage, and grammar structure are challenging in learning and using. There is a gap from knowing the language to using it, so to increase the practice opportunities in EFL class is a way to fill this gap between knowing and using. The more the students practice, the more they are familiar with the grammatical knowledge and language feature. In this situation, it is still useful and necessary to learn the vocabulary, expression, sentence structure, context, and grammar knowledge for EFL writing. So, the EFL teachers have responsibilities to increase the practice opportunities to use the language knowledge, to support the learning in EFL writing and monitor the students' learning progress. The purpose of learning a language is to use it, if learners cannot produce in written, then they have to go back and learn the grammatical knowledge and language feature fully and maturely.

The teachers need to know the importance of practicing and using the learnt knowledge, it is not necessary always to present new language content for their students to learn, but to be familiar with the leant things. Many students said that their teachers often ask them to retell or recite the article in their textbooks. This is a phenomenon that reading and speaking have a heavy weight in EFL class, since reading has a big portion in examination, while promoting speaking is the goal of curriculum in China. Why not rehearsed the article in written form, since rehearsed the article in writing can be done by all students at one time, by contrast, to retell or recite is only for one student at one time. The teachers can mark them and feedback to students after class, especially in big EFL classes in the junior high schools in China, which saves time in class. That the way to link the reading and writing skills (Fitzgerald \& Shanahan, 2000), the dictation technique merging the listening and writing (Nation \& Newtown, 2009), and an integration of the 4/3/2 speaking activity and writing for fluency development (Yang, 2014), are the opportunities to integrate the four skills in EFL teaching.

\subsection{Exploring and using appropriate language learning strategies to support EFL writing}

Both the teachers and students think that there are few good strategies to support EFL writing that implies the effort in EFL writing is not enough. In reality, many students are translating from Chinese into English for an EFL writing task, while the teachers treat writing as a production task, not a process task. This is a problem left from the grammar translation period. For all that, the teachers are supposed to explore and demonstrate appropriate language learning strategies for their students to deal with EFL writing. Oxford (1990) provided a group of language learning strategies, for example, summary writing for the information gained through listening or reading task, rehearsing the language in a written task, repeating the speaking content by written practice, and so on. Thereinto, Khaki, Hessamy, Hemmati, and Iravani (2013) noticed that the students performed better in a reading-to-writing task by the control of vocabulary and grammar, than those did in a writing-only task with difficult in planning and writing, though they had a good feeling.

Richards (2008) summarised technology and internet help to promote the language learning from a teacher-centred domination to learner-centred position, so the role of teacher is more like an instructor. Additionally, Storch (2011) argued either online writing outside class, or face-to-face collaborative writing is a good strategy with various benefits, for instance, online collaborative writing can save time in class and is possible to approach the native English language environment. Many teachers discussed this issue in the interview, they tried to encourage collaborative writing and many teachers failed to do so, while they were also worried about the students getting wrong answer or feedback from the peer learning. On the other hand, the students usually think they can get right answer and support from their teachers only. Instead they should change their opinion that learning and feedback is from their peers, too. 


\subsection{To integrate L1 and L2 to overcome the first language barrier}

Under the traditional grammar translation teaching trend, both teachers and students used L1 as a tool to learn English, in contrast to communicative language teaching, some teachers misunderstood the concepts of communicative language teaching - the $\mathrm{L} 1$ is banned in class (Wu, 2008), that also refers to the English only policy based on unexamined theories and assumptions (Auerbach, 1993). The students are not sure that the gap between L1 and L2 cause the writing problem. From the interview, some of the students told that in their EFL writing process, they process vocabulary and meaning in Chinese and then translate them into English. This is similar with Friedlander's (1990) finding that the Chinese speakers would be beneficial if writing in English about a Chinese topic, since they can plan in Chinese first and then use the plan to produce the English texts. However, Nation (1997) encouraged using L1 to explain the instruction and procedure for a task where confusion would be resulted if it is through the L2 and he further pointed out that using L1 to explain the vocabulary usage and grammar structure could show the L1 is a valuable tool in support EFL learning. Therefore, the teachers should balance the L1 and L2 use in class in order to go across the first language's obstacle. Moreover, the teachers are advised to choose a particular approach for EFL writing (Yu, 2012), for example, process writing and content-based approach, that help the students to practice the EFL writing process and content since the Chinese language is often with a lot metaphors. Yu (2012) concluded with the student's awareness and teacher's help, the discourse and pragmatic problems can be overcome by improving the EFL writing.

\subsection{To keep the learning ongoing to make progress in EFL writing}

Beside the discussion about grammatical knowledge, curriculum support, teacher's feedback, and good language learning strategies, the EFL students are required to cultivate confidence and autonomy in learning and practice. However, nearly half of the students concerned ongoing learning for writing. These students strongly believe that EFL writing is a trainable skill according to their Chinese language writing experience. In this case, journal writing as a regular work is consciously suggested in the junior high schools in China. Chiramanee and Kulprasit (2014) found students had positive attitudes toward journal writing and journal writing increases the EFL students' writing ability. It proved that journal writing is a great technique to cultivate collaborative learning and learner-centred antimony in the EFL class especially in the academic writing settings in Asian countries. Along the same line, Tuan (2010) substantiated the benefits of journal writing, which is an extensive activity to enhance the EFL writing skill, but also to build a close cooperation between the teachers and students. Journal writing eventually fostered the EFL learners' writing motivation and confidence. To sum up, as long as the learners keep writing journal freely and autonomously, there will be a forward progress in EFL writing.

Positive attitude, or motivation, is a key driver to keep the learning and practice ongoing. Cho and Teo (2012) found that when the teachers used and adapted motivational strategies in EFL class, their students' learning motivation could be improved. Once the students become more motivated, they will be more successful in EFL learning. Dörnyei (2001) argued motivation is an important cognitive factor to develop EFL writing, so the teacher is defined as an instructor in the EFL class to encourage the students and to monitor their achievements as well. Hedge (2005) mentioned that process writing is an effective method to teach EFL writing that focuses on creating texts, supported by different stages: starting from being motivated, then to write and to get ready for publication. Writing is not a single skill, but it links listening, speaking, and reading skills. In particular, the dictogloss activity (Wajnryb, 1990) is a technique mainly to link the listening and writing skill, which encourages the learners to focus on both form and meaning of a language. Ellis (2003) suggested that the dictogloss activity is based on communication, which can be used in task-based language learning approach, which supports the less confident students to speak in groups to negotiate the forms and meanings (Gibbons, 2009). Moreover, writing is not only a production task, but also possible to be integrated with listening, speaking or reading tasks, to motivate the students effectively. 
The teachers or the students themselves are better to be clear with the learning goals, the plans of learning, and the progresses of learning. Some of the students participating in the survey did not realise the importance to reflect their learning of EFL writing. The teachers noticed that reflecting the quality of teaching and learning is necessary and useful. When teaching an EFL writing course or designing its curriculum, to perform a need analysis is always a good idea before, during and post the writing course. Nation and Macalister (2010) stated to conduct a needs analysis for the language learners is extremely important to identify the learners' attitudes towards the course syllabus, meanwhile it is worth looking for ways in case of the learners who have negative attitudes towards learning a language. If the learners have positive attitudes towards learning writing skill, they will have motivation to be succeeded in EFL writing. Luckily, most teachers and students believe that the EFL writing can be improved with efforts and training. The students are even more confident than the teachers about this concern.

What is more, Brown (2001) suggested English language teaching with diagnosis, treatment and assessment. The feature and performance of EFL writing can be diagnosed by checking the linguistic knowledge including vocabulary, spelling and sentence structure, discourse and pragmatic organisation, logic planning, cognitive process, creative thinking, emotion, and motivation (Williams, 2007). Zhao (2014) summarised the practice of EFL writing could promote language learning and enhance students' thinking ability, as a result students are encouraged to do paraphrasing or summarizing work frequently. While, the treatment to EFL writing enables the teachers and students to monitor and adjust learning progress, to revise activities, lessons, and curriculum, and to reflect what went right and wrong in the writing course. The students should be aware of these reflections that can be shared with their teacher in individual interview, a regular session to interact between the EFL teacher and students. According to the feedback in interview, the teachers did not provide explanation or feedback, but usually provide a sample writing script. For the purpose of writing is more than a final production, the assessment of writing is about the goal, preparation, process, and outcome of the EFL writing.

\section{Conclusion}

\subsection{Limitation}

One limitation of this study is the sample size is too small, it is better to conduct this study again with a big sample at different junior high schools in China. On the other hand, this study is in the light of an overall attitude to EFL writing, more investigation of the specific teaching and learning attitude towards EFL writing could be done in the future.

\subsection{Summary}

In Conclusion, this study scrutinized EFL teachers' and students' attitudes, in terms of their worries, perceptions and beliefs, with regards to EFL writing in primary schools. Both the teachers and students have a similar and positive attitude towards EFL writing, while the results observed from a paired t-test indicated that they considered EFL writing as a difficult and important skill, but they believed that it is possible to improve their EFL writing skill. On the other hand, the findings in the individual facet-to-face interview justified that the root reasons of writing is a weak skill and there were relevant strategies to overcome the difficulties in performing EFL writing. The students had more worries and perceptions in EFL writing, though they were more confident than their teachers in order to achieve the goals for EFL writing. This study finally contributed some pedagogical suggestion in teaching and learning EFL writing: (i) to increase the practice opportunities, (ii) to use correct language learning strategies, (iii) to overcome the first language barrier, (iv) to keep ongoing learning, and (v) to reflect the quality, process, and outcome of EFL writing, which are effective ways to enhance the EFL writing attitude and skill in the primary schools. 


\section{References}

Akkaya, N., \& Kirmiz, F. S. (2010). Relationship between attitudes to reading and time allotted to writing in primary education. Procedia Social and Behavioral Sciences, 2(2), 4742-4746. http://dx.doi.org/10.1016/j.sbspro.2010.03.761

Auerbach, E. R. (1993). Reexamining English only in the classroom. TESOL Quarterly, 27, 9-32. http://dx.doi.org/10.2307/3586949

Baker, C. (1988). Key issues in bilingualism and bilingual education. Clevedon, Avon: Multilingual Matters.

Brown, D. (2001). Teaching by principles: An interactive approach to language pedagogy (2nd ed.). New York: Pearson Education.

Chiramanee, T., \& Kulprasit, W. (2014). Journal writing with peer feedback: A friend or a foe for EFL learners. International Journal of English Language Education, 2(2), 142-153. http://dx.doi.org/10.5296/ijele.v2i2.6038

Cho, E. Y., \& Teo, A. (2013). EIL teachers' motivational strategies and students' preference in the deep southern part of Thailand. International Journal of English Language Education, 2(1), 15-31. http://dx.doi.org/10.5296/ijele.v2i1.4418

Choi, Y. H. (1988). Text structure of Korean speakers' argumentative essays in English. World Englishes, 7(2), 129-142. http://dx.doi.org/10.1111/j.1467-971X.1988.tb00226.x

Cohen, L., Manion, L., \& Morrison, K. (2007). Research methods in education (6th ed.). London: Routledge.

Creswell, J. (2012). Educational research: Planning, conducting and evaluating quantitative and qualitative research. Pearson.

Creswell, J. W. (2013). Research design. Sage.

Dörnyei, Z. (2001). Motivational strategies in the language classroom. Cambridge: Cambridge University Press. http://dx.doi.org/10.1017/CBO9780511667343

Dörnyei, Z., \& Csizér, K. (2002). Motivational dynamics in second language acquisition: Results of a longitudinal nationwide survey. Applied Linguistics, 23, 421-462. http://dx.doi.org/10.1093/applin/23.4.421

Ellis, R. (1994). The study of second language acquisition. Oxford: Oxford University Press.

Ellis, R. (2003). Task-based language learning and teaching. Oxford: Oxford University Press.

Fakeye, D. (2010). Students' personal variables as correlates of academic achievement in English as a second language in Nigeria. Journal of Social Sciences, 22(3), 205-211.

Friedlander, A. (1990). Composing in English: Effects of a first language on writing in English as a second language. In B. Kroll (Ed.), Second language writing: research insights for the classroom. Cambridge: Cambridge University Press. http://dx.doi.org/10.1017/CBO9781139524551.012

Fitzgerald, J., \& Shanahan, T. (2000). Reading and writing relations and their development. Educational Psychologist, 35, 39-50. http://dx.doi.org/10.1207/S15326985EP3501_5

Gardner, R. C. (1980). On the validity of affective variables in second language acquisition: Conceptual, contextual, and statistical consideration. Language Learning, 30, 255-270. http://dx.doi.org/10.1111/j.1467-1770.1980.tb00318.x

Garner, R. C. (1985). Social psychology and second language learning: The role of attitudes and motivation. London: Edward Arnold.

Gardner, R., \& Lambert, W. (1972). Attitudes and motivation in second language learning. Rowley, MA: Newbury House.

Gay, L. R., Mills, G. E., \& Airasian, P. (2006). Educational research: Competencies for analysis and applications (8th ed.). Upper Saddle River, New Jersey: Pearson Education Ltd.

Gibbons, P. (2009). English learners, academic literacy, and thinking. Portsmouth, NH: Heinemann.

Grix, J. (2004). The foundations of research. London: Palgrave Macmillan.

Gonzalez, V., Chen, C., \& Sanchez, C. (2001). Cultural thinking and discourse organizational patterns influencing writing skills in a Chinese English as a foreign language (EFL) learner. Bilingual Research Journal, 25(4), 417-442. http://dx.doi.org/10.1080/15235882.2001.11074470 
Yang, Y.

Harris, G. J., \& Cunningham, H. D. (1994). The Simon and Schuster guide to writing. New Jersey: Prentice Hall, Englewood Cliffs.

Hedge, T. (2005). Writing. Oxford: Oxford University Press.

Ingels, M. (2006). Legal communicative skills. Culemborg: ACCO.

Ingram, D. E., \& Wylie, E. (2007). The international second language proficiency ratings. Brisbane: ISLPR Language Services.

Karahan, F. (2007). Language attitudes of Turkish students towards the English language and its use in Turkish context. Journal of Arts and Sciences, 7, 73-87.

Kobayashi, H. (1984). Rhetorical patterns in English and Japanese. Dissertation Abstract International, 45(8), 24-25. http://dx.doi.org/10.2307/3586587

Lambert, W. E. (1967). The social psychology of bilingualism. Journal of Social Issues, 23, 91-109. http://dx.doi.org/10.1111/j.1540-4560.1967.tb00578.x

Latif, M. A. (2007). The factors accounting for the Egyptian EFL university students' negative writing affect. Essex Graduate Student Papers in Language \& Linguistics, 9, 57-82.

Lee, S. (2003). Teaching EFL writing in the university: Related issues, insights, and implications. Journal of National Taipei Teachers College, 16(1), 111-136.

Liu, J. J. (2010). English writing in public high schools in China and America: A comparison analysis. The International Journal of Language Society and Culture 30, 54-62.

MacIntyre, P. D., \& Gardner, R. C. (1989). Anxiety and second language learning: Toward a theoretical clarification. Language Learning, 39(2), 251-275. http://dx.doi.org/10.1111/j.1467-1770.1989.tb00423.x

Masgoret, A. M., \& Gardner, R.C. (2003). Attitudes, motivation, and second language learning. A meta-analysis of studies conducted by Gardner and associates. Language Learning, 53, 123-163. http://dx.doi.org/10.1111/1467-9922.00212

Mathewson, G. (1994). Model of attitude influence upon reading and learning to read. In R. Ruddell, M. Ruddell, \& H. Singer (Eds.), Theoretical models and processes of reading (4th ed., pp. 1131-1161). Newark, DE: International Reading Association.

Murcia, M., \& Olshtain, E. (2000). Discourse and context in language teaching: A Guide for language teachers. Cambridge: Cambridge University Press.

Nation, I. S. P. (1997). L1 and L2 use in the classroom: A systematic approach. TESL Reporter, 30(2), 19-27.

Nation, I. S. P., \& Macalister, J. (2010). Language curriculum design. New York: Routledge.

Nation, I. S. P., \& Newton, J. (2009). Teaching ESL/EFL listening and speaking. New York: Routledge.

Okasha, M. A., \& Hamdi, S. A. (2014). Using strategic writing techniques for promoting EFL writing skills and attitudes. Journal of Language Teaching \& Research, 5(3), 674-681. http://dx.doi.org/10.4304/jltr.5.3.674-681

Oxford, R. (1990). Language learning strategies: What every teacher should know. New York: Newbury House.

Pickard, N. (1996). Out-of-class language learning strategies. ELT Journal, 50(2), 151-159. http://dx.doi.org/10.1093/elt/50.2.150

Richards, J. C. (2008). Growing up with TESOL. English Teaching Forum, 46(1), 2-11.

Schibeci, R. A., \& Riley, J. P. (1986). Influence of students background and perceptions on science attitudes and achievement. Journal of Research in Science Teaching, 23, 177-187. http://dx.doi.org/10.1002/tea.3660230302

Scotland, J. (2012). Exploring the philosophical underpinnings of research: Relating ontology and epistemology to the methodology and methods of the scientific, interpretive, and critical research paradigms. English Language Teaching, 5(9), 9-16. http://dx.doi.org/10.5539/elt.v5n9p9

Sever, S. (2000). Turkish education and exact learning. Anı Publishing, Ankara.

Seyabi, F., \& Tuzlukova, V. (2014). Writing problems and strategies: An investigative study in the Omani school and university context. Asian Journal of Social Sciences \& Humanities, 3(4), 37-48.

Starks, D., \& Paltridge, B. (1996). A note on using sociolinguistic methods to study non-native attitudes towards English. World Englishes, 15(2), 217-224. http://dx.doi.org/10.1111/j.1467-971X.1996.tb00107.x 
An investigation of Chinese junior high school teachers' and students' attitudes towards EFL writing

Storch, N. (2011). Collaborative writing in L2 contexts: Processes, outcomes, and future directions. Annual Review of Applied Linguistics, 31, 275-288. http://dx.doi.org/10.1017/S0267190511000079

Khaki, N., Hessamy, G., Hemmati, F., \& Iravani, H. (2013). Exploring EFL writers' attitudes towards reading-to-write and writing-only test tasks: A qualitative approach. The Journal of Asia TEFL, 10(1), 47-68.

Tuan, L. T. (2010). Enhancing EFL learners' writing skill via journal writing. English Language Teaching, 3(3), 81-88. http://dx.doi.org/10.5539/elt.v3n3p81

Wajnryb, R. (1990). Grammar dictation. Oxford: Oxford University Press.

Wenden A. (1991). Learner strategies for learner autonomy. Englewood Cliffs, N. J: Prentice Hall.

Williams, J. (2007). Teaching writing in second and foreign language classrooms. Beijing: World Publishing Corporation.

Wu, W. (2008). Misunderstandings of communicative language teaching. English Language Teaching, 1(1), 50-53. http://dx.doi.org/10.5539/elt.v1n1p50

Yang, Y. I. J. (2014). The development of speaking fluency: The 4/3/2 technique for the EFL learners in China. International Journal of Research Studies in Language Learning, 3(4), 55-70. http://dx.doi.org/10.5861/ijrsll.2013.624

Yu, A. (2012). Analysis of the problems of the Chinese college students' EFL classroom writings. International Education Studies, 5(5), 199-203. http://dx.doi.org/10.5539/ies.v5n5p199

Zamel, V. (1983). The composing processes of high ESL students: Six cases students. TESOL Quarterly, 17, 165-187. http://dx.doi.org/10.2307/3586647

Zhao, P. (2014). The model of "Plan Do Check and Act" to improve Chinese EFL learners' writing strategies. Higher Education of Social Science, 7(1), 107-112. 
Yang, Y.

Appendix I

Survey

Instruction

1) This survey is confidentially used from research purpose only

2) Please do not talk or share with your ideas with other participants

3) Please answer each question below

4) There is a Chinese version available

5) Please ask for help if you cannot understand anything

Part 1: Please tick your gender and role with the following boxes Demographical information

$\square$ Male $\square$ Female $\quad \square$ Teacher $\square$ Student

How old are you? years old

$\square \quad$ If you are an EFL teacher, how many years have you been teaching? years

$\square \quad$ If you are an EFL teacher, what qualification do you hold?

Part 2: Rate from 1 to 5 scales for the following statements. (1 - Strongly disagree, 2 - Disagree, 3 - Uncertain, 4 Agree, and 5 - Strongly agree)

\section{Worry}

Writing is a difficult productive skill when learning English as Foreign Language, because the vocabulary choice, grammar structure, and collocation usage are a challenge part for learning and applying;

From comprehensive to productive, there are differences and/or gaps existing between understanding and expression;

There are few good strategies to support EFL writing, meanwhile the effort put in EFL writing is not enough;

ESL writing is an important skill, but it is very difficult to emphasise and process ESL writing through communicative language teaching since speaking dominating the class;

\section{Perception}

There should be sufficient resources from the teacher, syllabus, and curriculum to support EFL writing's teaching and learning procedure;

Attention should be paid on culture barriers and the obstacle between L1 and L2 while engaging EFL writing;

Language learning strategies are important in EFL writing and there should be relevant supports from the EFL teachers and learners in the EFL class;

A lack of writing practice in EFL class in terms of the amount of time, tasks, training techniques, and output/productive opportunities; 


\section{Beliefs}

Beside the language knowledge, the support from teacher and curriculum, getting valuable feedback from the learning and performing of EFL writing is also a motivational factor;

Language knowledge is learnt to accompany culture knowledge in order to write accurately and naturally;

That to reflect the quality of teaching and learning the EFL writing with relevant strategies is necessary and helpful;

The EFL writing skill can be improved by sufficient effort, professional training and ongoing practice.

Part 3: Final comments

Are there any other comments you would like to make about this issue?

This is the end of the questionnaire, thank you for your participation! 
Yang, Y. 